\title{
THE EFFECTIVENESS OF CATEGORIES GAMES IN TEACHING VOCABULARY
}

\author{
Husnul Khotimah; I Made Permadi Utama \\ Tomnjerry.lovers@yahoo.com; permadiutama47@gmail.com \\ Prodi Pedidikan Bahasa Inggris, FPBS IKIP Mataram
}

\begin{abstract}
The aim of this research is to find out whether Categories Games is effective or not in teaching vocabulary to the second grade students of SMAN 1 Sikur. This research was True Experimental with posttest-only control design. The object of this research was second grade students of SMAN 1 Sikur. The total numbers of population were 150 students. The technique to take the sample was cluster random sampling, which took 40 students as the sample in this research. At the first time, the researcher gave Pre test to the experimental and control group. The second time, the researcher gave the treatment that used Categories Games in experimental group and Puzzle Game in control group, then the last, the researcher gave post test both of group. From the data is obtained, it found that T-test was 6,96 and t-table at significance level of $0,05(95 \%)$ was 2,02 . So it means that the score of t-test was higher than t-table $(6,96$ $>$ 2.02). The alternate hypothesis (Ha), which used Categories Games in teaching vocabulary to the second grade of SMAN 1 Sikur was effective absolutely accepted. Meanwhile, the Null Hypothesis (Ho), which used Categories Games in teaching vocabulary to the second grade of SMAN 1 Sikur is not effective is absolutely rejected. Effectiveness of Categories Games was suitable for teaching vocabulary beside that practicable and applicable for English subject especially in teaching vocabulary.
\end{abstract}

Keywords: Effectiveness, Categories Games, and Teaching Vocabulary.

\section{INTRODUCTION}

There are various purposes of teaching English in Indonesia which has been stated in curriculum 2013. One of the main purposes is to develop the students' language skill in listening, speaking, reading and writing skill in English. However, those skills are unable to well construct without encouraging by components of language such as vocabulary, grammar, and pronunciation. This means that students` vocabulary mastery should be developed prior to supporting the four language skills. Rivers in Nunan (1991: 117) argues that the acquisition of an adequate vocabulary is essential for successful second language use because without an extensive vocabulary we will be unable to use the structures and functions we may have learned for comprehensible communication. In the field of education, including English education in Indonesia, our education is still dominated by the view that knowledge is a set of facts, which have to be memorized. It can be seen in teaching learning process focuses on teacher as prominent source of knowledge. As a result, students to be passive in teaching learning process, when the teaching learning process teacher only focuses on students' memorize in material not focus on component especially for vocabulary, as what they usually get is something difficult in learning vocabulary. Many students can serve good level of memorization of teaching material but at the end of teaching learning process, they actually do not understand it at all.

Teaching and learning process has to make it possible for students to understand the meaning of their learning material. Considering the importance of 
implementing in teaching English, the researcher decides to carry out a research on the role of using Categories Games in helping the teachers to rise up students' interest in learning English vocabulary for the second grade students at SMAN 1 Sikur.

The problem of this investigation relates to the students' vocabulary mastery after having some regular teaching by using game "Categories Games". The purpose of this investigation is to know whether categories games is effective or not in teaching vocabulary to the second grade students of SMAN 1 Sikur.

\section{Vocabulary}

Recognition of the meaning making potential of words means that vocabulary became a learning objective in its own right. McCarthy (1990: 2) in his book Vocabulary and Language Teaching. States vocabulary is the biggest component of any language. If you do not know enough vocabulary, you will not be able to express yourself adequately.

\section{Teaching Vocabulary to Young Learners}

Teaching vocabulary to young learners is different from teaching to adults. Susan House (1997) in her book entitled An Introducing to Teaching English to Children says, .....then by trying to understand better how children learn we will have more understanding on how to teach them".

\section{Techniques of Language in Teaching}

According to Freemen (1986: 136) in her book Techniques and Principles in Language Teaching, there are five kinds of language teaching techniques, they are: 1. Reconstructing Scramble Sentences
The students are given a passage (a text) in which the sentences are in scramble order. They are told to unscramble the sentence so that the sentences are constructed to their original order. They learn how sentence are bound together.

2. Performing Language Games

Games are used frequently in the constructive approach. The students find them enjoyable, and if they are properly designed, they give students valuable communicative practice. Games that are truly communicative, according to Morrow (in Johnson and Morrow: 1981), have their features of communication: information gap, choice, and feedback.

3. Presenting Picture Strip Story

In the activity, the teacher observes, one student in a small group is given a strip story. She or he shows the first picture of the story to the other members of her or his groups and asked them to predict what the second picture will look like. They receive feedback, not on the form but on the content of the prediction, by being able to view the picture and compare it with their prediction.

4. Role Play

Role-plays are very important in communicative approach because they give students an opportunity to practice in different social context and different social roles. Role play can be set up so that they are in a less structured way (example, based on for the teacher to tell the students who they are, what the situation is and what they are talking about, but the students determine what they intend to do).

5. Authentic Material 
To overcome the typical problem that students cannot transfer what they learn in the classroom to the outside world and to expose students to natural language in a variety of situations, adherents of the Communicative Approach advocate the use of authentic language materials. In this lesson, the teacher uses a copy of an original newspaper articles. He or she also assigns the students homework, requiring they listen to a live radio or television.

\section{Games}

In addition Hadfield (1998: 4) in his book entitled Elementary Vocabulary Games says a game is or activity with rules, a goal, and element of fun, which is divided into two kinds; competitive games, in which players or teams race to be the first to reach the goal, and cooperative games, in which players or teams work together towards a common goal. Games are activities that children naturally and universally are engaged in. There is timelessness in the pleasure. To play game is to enjoy competing alone or in groups against other players. In playing game, they do not think consciously about the language involved in doing so.

\section{Categories Game}

Categories Game is a kind of word games. It is an excellent game that can be played ordinarily by using pencils/pens and paper. The learners can word individually, in pair or in small group. On a piece of paper, they draw up a word with Categories chosen. Categories Game is easy and can be adapted for most any age group. Categories Games can be almost anything. Because this game is applied as the game for improving student vocabulary, so that the Categories can be the name of lexical set: Things that are green, things that are red, thangs that are white, things that are blue (Steven J, and Bill, 1999: 36).

\section{Teaching Vocabulary Using Categories Games}

Vocabulary as language component plays important role in language learning because of its importance, learners should be able to master it well. Mastering vocabulary is not easy to be implemented due to consider the way to teach vocabulary, so that learners will have great enthusiasm in learning vocabulary. However, games can be chosen by the English teacher as teaching to teach the language. The Categories Games help and encourage many learners to sustain their interest and done. Categories Games also help the teacher to create contexts in which the language is useful and meaningful. The learners want to take part in teaching and learning process so must understand what others are saying or have written, and they must speak or write in order to express their own point of view or give information.

\section{METHOD}

According to Kothari (2004: 5) experimental research is characterized by much greater control over the research environment and in this case some variables are manipulated to observe their effect on other variables. The research of the study is true experimental with two 
groups pretest-posttest design. In this research, the researcher gives different treatments for two groups. The group, which is treated by using Categories Games is named experimental group and control group which is treated by using small group discussion. Pre-test will be given before the treatment and post-test after the treatment. The researcher uses test as the instrument. the researcher uses cluster random sampling technique to select the group. From 150 populations, the researcher will take two classes as sample, those are class IPS 1 consist of 20 students as experimental group and class IPS 2 consist of 20 students as control group. So, the total of the sample is 40 students.

\section{Pre-test}

At the first meeting, the researcher gives the students 20 items of question to measure the students' competence before giving the treatment. The result of the test will be calculated for the data compared with the result of the post-test.

\section{Post-test}

The next procedure is post-test. This test will be conducted after pre-test and treatment are given to the students. The result of the test will be counted for the data. Finally, the result of this test showed the students' capability after the different treatments given. The test consists 20 items of questions. The test will be scored 5 for each item answered correctly in questions of test. The highest possible score will be 100 and the lowest possible score will be 0 . Individual scores of group are analyzed statically as the consideration in drawing conclusion of the research.

After obtaining the score of the students, the researcher kept on the score with the following steps. The first, a researcher consulted the students score and also calculated the mean score of pretest, mean score of post-test, variance of pre-test, variance of post-test and t-test from pre-test and post-test.

The researcher calculates the mean of all the samples (students), for this purpose the writer applied the following simple formula: Mean is the technical term for what is usually called the average. It is found by adding together every score and dividing the total by the number of scores.

1. The mean score for variable $X_{1}$

$$
\mathrm{M}_{1}=\frac{\sum x 1}{N 1}
$$

2. The mean score for variable $X_{2}$

$$
\mathrm{M}_{2}=\frac{\sum x 2}{N 2}
$$

The researcher calculated the variance of all the sample (students). For this purpose, the writer applied the following simple formula: Variance is an alternative approach to square each deviation, this leads to an alternative measure of dispersion knew as the variance.

1. Variance for Experimental Group

$$
S_{1}^{2}=\frac{\sum x_{1}^{2}}{N_{1}}-\overline{X_{1}^{2}}
$$

2. Variance for Control group

$$
S_{2}^{2}=\frac{\sum X_{2}^{2}}{N_{2}}-\overline{X_{2}^{2}}
$$

Finally, the writer used this formula to significance deviation of two mean scores the final result after several stages of the research that has been done as a pre-test, treatment and post-test and multiple stages of evaluation. 
E-Link Journal

Vol. 5 No. 2 (2018)

p-ISSN: 2085-1383; e-ISSN: 2621-4156

$\mathrm{t}=\frac{\left(\overline{X_{1}}-\overline{X_{2}}\right) \sqrt{\left(N_{1}+N_{2}-2\right) N_{1} N_{2}}}{\sqrt{\left(N_{1} S_{1}^{2}+N_{2} S_{2}^{2}\right)\left(N_{1}+N_{2}\right)}}$

\section{FINDINGS AND DISCUSSION}

The finding of this research in post-test for experimental it can be seen as follows:

$$
\begin{aligned}
S_{1} & =\frac{\sum X_{1}^{2}}{N_{1}}-\bar{X}_{1}^{2} \\
& =\frac{123,200}{20}-78,0^{2} \\
& =6,160-6,084 \\
& =76,0
\end{aligned}
$$

Based on the result of post-test of the experimental group, the research found the mean score was 78,0 and the standard deviation was 76,0.

The finding of this research in post-test for control it can be seen as follows:

\section{Table 2.}

The Final Score of Post-Test for Control Group

D. Billy 85

2. Aminatul Zahra 80

3 Baiq Muzaemah 75

4 Bonifasius Janu 80

Ardianus Lado

Danil Widi Atmojo

Dian Fitriani

Eska Agustina

Fendi Rahman

Hardi Sandi

Harian Jayadi

Hasnah

Hurniah

Indri Sofiana

Junaidi

Muniarti B

16 Novan Agus Dian

Putra

17 Rahmin

18 Roberto Andika

Padeng

19 Sa'ban

Winda Larasani S

\begin{tabular}{ccc}
20 & Winda Larasani S & 80 \\
\hline & Total & $\mathbf{1 5 6 0}$ \\
\hline Mean $\overline{\mathbf{x}}$ & & $\mathbf{7 8 , 0}$
\end{tabular}

a. Mean

$$
\begin{aligned}
M_{1} & =\frac{\sum x 1}{N 1} \\
& =\frac{1560}{20} \\
& =78,0
\end{aligned}
$$

b. Standard deviation of post-test for experimental group a. Mean

$$
\begin{aligned}
M_{2} & =\frac{\sum x 2}{N 2} \\
& =\frac{1480}{20} \\
& =74,0
\end{aligned}
$$

b. Standard deviation of control group 


$$
\begin{aligned}
& S_{2}=\frac{\sum X_{2}^{2}}{N_{1}}-\bar{X}_{2}^{2} \\
& =\frac{110,950}{20}-74,0^{2} \\
& =5,548-5,476 \\
& =0,07
\end{aligned}
$$

Based on the result of post-test of the control group, the researcher found the mean score was 74,0 and the standard deviation was 0,07 .

Then, to know the effect of Categories Games on students' vocabulary, the researcher used this formula:

$$
\begin{aligned}
t=\frac{\left(\bar{X}_{1}, \bar{X}_{2}\right) \sqrt{\left(N_{1}+N_{2}-2\right) N_{1} \cdot N_{2}}}{\sqrt{\left(N_{1} \cdot S_{1^{2}}+N_{2} \cdot S_{2^{2}}\right)\left(N_{1}+N_{2}\right)}} \\
=\frac{(78,0-74,0) \sqrt{(20+20-2) 20 \times 20}}{\sqrt{(20 \times 76,0+20 \times 0,07)(20+20)}} \\
=\frac{(4,0) \sqrt{38 \times 20 \times 20}}{\sqrt{(1.520+1,4)(40)}} \\
=\frac{(4,0) \sqrt{15200}}{\sqrt{1,522 \times 40}} \\
=\frac{4,0 \times 123.28}{\sqrt{60,88}} \\
=\frac{493,12}{70,80} \\
=6,96
\end{aligned}
$$

The result of t-table with degree of freedom N-2 that was $(20+20-2)=38$. The result of the t-table was 2,02. The result of post-test calculation shows that $\mathrm{t}$ test higher than t-table $(6,96>2,02)$.

After carrying out the research, and the researcher knew the students' competence after they were given pre-test. The researcher found that there was significance result of vocabulary treatment between the experimental and control group after they were given different treatment. The students who were using Categories Games got higher score than those who were taught using Puzzle Games, it can be seen that the mean score of post-test for experimental group was 78,0 , while the mean score of post-test for control group was 74,0. And then the mean score of t-test in post-test that was higher than t-table $(6,96>2,02)$.

Based on the result of this research the researcher concluded that there was significant effect in teaching English vocabulary between the students who were taught by using Categories Games and those who were taught using Puzzle Games. It can be seen in teaching English vocabulary using Categories Games that was used in the experimental group that gave a significant contribution to the students' vocabulary achievement. It can be concluded that hypothesis alternative was accepted.

\section{CONCLUSION}

The researcher finally comes forward to the conclusion as follows: The result of hypothesis testing by using $t$-test proves that Ho or null hypothesis was rejected. It means that Categories Games was effective in teaching vocabulary at the second grade student of SMAN 1 Sikur.

\section{REFERENCES}

McCarthy, Michael. 1990. Vocabulary and Language Teaching. London: Longman 
Johnson, K, \& K, Morrow. 1981. House, Susan. 1997. An Introduction to Communication in the Classroom Application and Method for a Communicative Approach. Oxford: Oxford University Press.

Nunan, D. 1991. Language Teaching Methodology. New York: Phoenix ELT Singh, K. Yogesh. 2006. Fundamental of Research Methodology And Statistics. New International Publishers. Teaching English to Children. London: Richmond Publishing.

Freeman, L. Diane. 1986. Technique and Principles in Language Teaching. New York: Oxford University Press.

Hadfield, Jill. 1998. Elementary Vocabulary Game. England: Longman.

Kothari, C.R. 2004. Research Methodology: Methods and Techniques. New Delhi: New Age International (P) Ltd., Publishers. 